\title{
Host plant identity and condition shape phytophagous insect communities on urban maple (Acer spp.) trees
}

\author{
Dávid Korányi ${ }^{1,2} \oplus \cdot$ Viktor Markó $^{3}$
}

Received: 8 February 2021 / Accepted: 4 January 2022 / Published online: 21 January 2022

(c) The Author(s) 2022

\begin{abstract}
By mitigating the negative effects of urbanization, urban trees contribute significantly to the well-being of urban citizens. However, trees themselves are also exposed to urban stress that can influence tree condition and tree-herbivore interactions. Maple species (Acer spp.) are among the most commonly planted trees in urban areas throughout North America and Europe. Among these species, field, sycamore, and Norway maple are native to Europe, but tolerate environmental stress to varying degrees. Here, we compared the phytophagous insect communities in the canopy of these tree species in the city of Budapest, Hungary. We also examined the stress level [expressed as peroxidase (POD) enzyme activity], and physiological condition (expressed as degree of leaf necrosis and leaf fall) of the maple trees, and their relationship to herbivore abundance. We observed higher total abundance of phytophagous insects on field and sycamore maple compared to Norway maple. Most herbivorous species were associated with field maple, sycamore had the highest aphid densities, and Norway maple harbored the least specific phytophagous insect community. Field maple trees were in the best condition while Norway maple trees in the worst condition, i.e., with the highest proportion of necrotic leaf surface area. The super-abundant planthopper species, Metcalfa pruinosa positively affected the POD activity of trees, but did not influence their condition. On the contrary, M. pruinosa abundance was driven by tree condition, with higher numbers on healthier trees. Our findings suggest that the abundance of phytophagous insects in the canopy of maple trees is highly determined by tree condition, and in this study field maple had the highest and Norway maple the lowest tolerance for urban stress.
\end{abstract}

Keywords Acer spp. · Herbivores · Metcalfa pruinosa $\cdot$ POD activity $\cdot$ Urban trees

\section{Introduction}

Although urban areas represent a relatively small proportion of the total Earth surface, the urban land-cover continues to grow and is predicted to increase by 1.2 million $\mathrm{km}^{2}$ in the first 30 years of the 21 st century (Seto et al. 2012). Urban

Handling Editor: John J. Couture.

Dávid Korányi

koranyi.david@ecolres.hu

1 Institute for Wildlife Management and Nature Conservation, Hungarian University of Agriculture and Life Sciences, Deák Ferenc utca 16, H-8361 Keszthely, Hungary

2 "Lendület" Landscape and Conservation Ecology, Institute of Ecology and Botany, Centre for Ecological Research, Alkotmány út 2-4, H-2163 Vácrátót, Hungary

3 Institute of Plant Protection, Hungarian University of Agriculture and Life Sciences, Ménesi út 44, H-1118 Budapest, Hungary expansion and associated land-cover change is considered to be one of the most extreme forms of landscape and habitat transformation. It leads to dramatic changes in the local biotic and abiotic environment, and hence has substantial impacts on ecological systems (McDonnell and Pickett 1990; McIntyre 2000; Grimm et al. 2008).

Trees contribute to the mitigation of abiotic environmental changes associated with urbanization, thus have important role in providing a livable environment for humans. Urban trees reduce air temperature by absorbing solar radiation through evapotranspiration and reduce surface temperatures via shading (Rahman et al. 2017). Moreover, trees remove significant amounts of air pollutants originating from traffic and industrial activity, by absorption and by dry deposition on plant surfaces (Nowak et al. 2006). At the same time, trees are highly exposed to different factors associated with urbanization, including heat stress, increased emissions, low air humidity and periods of critical 
water stress, soil compaction, and de-icing salt (Sjöman and Nielsen 2010; Pautasso et al. 2015).

Tree species respond to urban stress differently. Species that are poorly adapted to these harsh conditions are increasingly losing their decorative value (Günthardt-Goerg and Vollenweider 2007; Swoczyna et al. 2015; Stratópoulos et al. 2019), and are becoming particularly susceptible to biotic stress agents (Richards 1983; Wargo 1996; Tubby and Webber 2010). Accordingly, knowledge about different species' tolerance and stress resistance is crucial during the selection of trees for urban sites (Richards 1983; Roloff et al. 2009; Sjöman and Nielsen 2010).

Environmental stressors can negatively affect plant defensive chemistry, while increased nutrient deposition and elevated atmospheric carbon dioxide associated with urbanization can promote plant growth. These effects, along with altered top-down control (see Raupp et al. 2010 and Miles et al. 2019 for review), may lead to outbreaks in insect herbivore populations on urban trees (White 1969, 1984; Price 1991). These herbivores can cause visible decline in tree condition (Zvereva et al. 2010). For example, piercingsucking insect pests can cause significant removal of nutrients, leading to reduced growth and survival, and weakened photosynthesis of trees (Dixon 1971; Kaakeh et al. 1992; Frank et al. 2013). Native species might be more exposed to these effects as they often support more local phytophagous species and receive increased herbivory (Tallamy 2004; Matter et al. 2012; Clem and Held 2015; Frank et al. 2019). Differences in abundance and composition of herbivore communities also occur within congener tree species due to numerous reasons, including phenological characteristics (Ekholm et al. 2019) and physiological condition of trees (Dale and Frank 2017), and host plant specialization of herbivores (Fraser 1997). Although a number of studies have been conducted examining the effects of the urban environment on plants and herbivores, more studies examining the ecology of plant-herbivore interactions, including how tree species shape herbivore communities in cities, are needed to get a more holistic picture (Raupp et al. 2010; Miles et al. 2019).

Maples (Acer spp.) are among the most commonly planted urban tree species in North America (Cowett and Bassuk 2014, 2020) and Europe (Sæbø et al. 2003; Britt and Johnston 2008; Sjöman et al. 2012). In Central Europe, sycamore (Acer pseudoplatanus L.), Norway (A. platanoides L.), and field maple (A. campestre L.) are common native tree species (Caudullo and de Rigo 2016; Pasta et al. 2016; Zecchin et al. 2016), and are often selected for urban forestry (Roloff et al. 2009). These tree species have overlapping phytophagous insect communities due to the presence of some generalist and maple specialist species (e.g., Jones 1945; Nickel 2003; Wilkaniec and Sztukowska 2008).
Within the genus Acer, field maple is phylogenetically most closely related to Norway maple while sycamore is distantly related to these two species ( $\mathrm{Li}$ et al. 2006). This relationship is partly reflected in their ecological preferences and stress tolerance. Field maple has a very wide ecological range and is relatively insensitive to soil parameters. It prefers relatively warmer climates, thus tolerates high temperatures and prolonged periods of dry soil (Zecchin et al. 2016). Norway maple can also cope with adverse environmental conditions (Sjöman and Nielsen 2010); however, does not tolerate conditions of high evapotranspiration or prolonged drought and grows best in deep, fertile and moist soils (Caudullo and de Rigo 2016). Similar to field maple, Norway maple is often recommended as ideal species for urban plantings (Roloff et al. 2009; Sjöman and Nielsen 2010). Although sycamore maple is very adaptable to different soil types, it has high demands of cool and moist growing conditions and does not tolerate excessive heat and limited water availability (Pasta et al. 2016). Therefore, sycamore maple is considered to be less suitable species for urban habitats (Roloff et al. 2009). However, the performance of these three Acer species and the outcomes of their interactions with herbivorous insects in urban environment has not been studied.

In this study, we examined the abundance patterns of phytophagous insects as well as their interactions with physiological condition of these three common Acer species in urban areas. Our first objective was to compare the composition and abundance of common pest insects on sycamore, Norway, and field maple trees. Our second objective was to assess how phytophagous insects influence the stress level and condition of trees. Finally, our third objective was to determine whether the condition of these trees may affect the abundance of phytophagous insects.

\section{Methods}

\section{Study area and arthropod collection}

The research was carried out in the city of Budapest between 2014 and 2015. We selected four study sites in

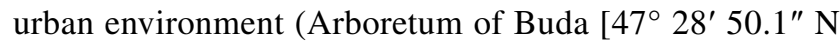

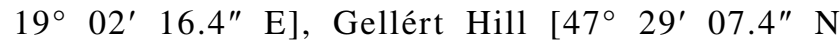
$19^{\circ} 02^{\prime} 38.7^{\prime \prime} \mathrm{E}$ ], streets around the Buda Campus of Szent István University [ $\left.47^{\circ} 28^{\prime} 40.3^{\prime \prime} \mathrm{N} 19^{\circ} 02^{\prime} 06.4^{\prime \prime} \mathrm{E}\right]$, and Alkotás utca $\left[47^{\circ} 29^{\prime} 20.1^{\prime \prime} \mathrm{N} 19^{\circ} 01^{\prime} 28.3^{\prime \prime} \mathrm{E}\right]$ ) that are situated close to each other and have sufficient numbers of field (A. campestre), Norway (A. platanoides), and Sycamore maples (A. pseudoplatanus). We selected 12 individuals (three at each site) in 2014 and 20 individuals (five at each site) per tree species in 2015 for arthropod collection, all of which had similar ages and undamaged trunks. 
Arthropods were collected from the canopy of the trees by the beating method (Basset et al. 1997), using a beating funnel $70 \mathrm{~cm}$ in diameter and $60 \mathrm{~cm}$ in depth, together with a $120 \mathrm{~cm}$ long beating stick. Ten branches were sampled per tree. Samples were taken on 14 dates in 2014 (April 6, 20, May 4, 18, June 1, 16, 29, July 13, 26, August 9, 24, September 7, 20 and October 5) and on seven dates in 2015 (May 7, June 16, July 8, 29, August 19, September 10 and October $3)$. The collected arthropods were counted and deposited at the Department of Entomology of Szent István University. We identified to species level the abundant phytophagous species among aphids (Hemiptera, Aphididae), psyllids (Hemiptera, Psylloidea), plant- and leafhoppers (Hemiptera, Auchenorrhyncha, collected only in 2015, except Metcalfa pruinosa [Say] which was collected in both study years), heteropterans (Heteroptera), and curculionids (Coleoptera, Curculionidae).

\section{Stress level and condition of trees}

To determine the stress level of the trees, we measured peroxidase (POD) enzyme activity. Peroxidases are considered as important stress indicators of plants because the levels of these defensive proteins increase considerably in response to both abiotic and biotic stressors (Pandey et al. 2017). PODs are an important component of the immediate response of plants to insect damage and their activity is often used as a measure of plant response to herbivore attack (War et al. 2012). In 2015, we collected leaves from the selected trees on July 30 and 31, when the highest abundance of phytophagous insects was detected, and transported the leaves in a cooler box to the laboratory of the Department of Applied Chemistry of Szent István University. For enzyme analyses, leaves were homogenized in $20 \mathrm{mM}$ sodium acetate, $\mathrm{pH} 7.8$ buffer containing $1 \%$ polyvinylpyrrolidone, $20 \%$ sucrose, $0.035 \%$ bovine serum albumin, $10 \%$ Triton X100. The tissue extract was centrifuged at $13,000 \mathrm{r} / \mathrm{min}$ for $20 \mathrm{~min}$. The procedure was carried out at $4{ }^{\circ} \mathrm{C}$ and the supernatant was used for further analyses. POD activity was determined by spectrophotometry in a $\mathrm{H}_{2} \mathrm{O}_{2}$ substrate with ortho-dianizidine used as chromogenic indicator $(\varepsilon=11.3)$ at $460 \mathrm{~nm}$ (Shannon et al. 1966) and expressed in units of peroxidase per ml. A unit of peroxidase was defined as an increase of 0.001 unit of absorbance for 90 seconds.

In 2015 , we evaluated visually the degree of leaf necrosis and leaf fall of trees. These symptoms are considered as suitable indicators of environmental stress and can be used to determine the condition of plants (Close et al. 1996; Dobrowolska et al. 2001; Schreuder et al. 2001; GünthardtGoerg and Vollenweider 2007; Khavaninzadeh et al. 2014). The evaluations were done in the second half of October, when leaf fall and leaf necrosis symptoms became apparent. The evaluations were done in five-point scales along ordinal conditional gradients (leaf necrosis: observed in less than 5\% [score: 1], between 5 and 20\% [score: 2], between 20 and $35 \%$ [score: 3], between 35 and 50\% [score: 4], and between 50 and $70 \%$ of the canopy [score 5]; degree of leaf fall: less than $10 \%$ [score: 1], between 10 and $25 \%$ [score: 2], between 25 and $40 \%$ [score: 3], between 40 and 50\% [score: 4] and between 50 and $60 \%$ [score: 5]).

\section{Data analyses}

We used $\mathrm{R}$ version 3.6.2 statistical environment ( $\mathrm{R}$ Core Team 2019) for all analyses. Before the analyses, insect abundance and POD activity were log-transformed to meet conditions of normality. The degree of leaf necrosis and leaf fall variables were handled as ordered factors in the models using the function "as.ordered" of R. For the analyses on the relationships between phytophagous insects and stress levels and condition of trees, we included the numbers of the most abundant phytophagous insect species (M. pruinosa, $n$ $=15912$ ) and groups (other plant- and leafhoppers [except M. pruinosa], $n=1886$; heteropterans [all species], $n=$ 1626; aphids [all species], $n=1154$ ) in 2015 and $p$ values were adjusted using the method of Benjamini and Hochberg (1995).

\section{Effect of tree species on the composition and abundance of phytophagous insects}

We performed non-metric multidimensional scaling (NMDS) to examine the effect of tree species on the community composition of abundant phytophagous insect species using Bray-Curtis dissimilarity as the distance measure, and the "metaMDS" function of "vegan" package version 2.5-6 (Oksanen et al. 2019). In order to obtain meaningful quantitative responses, only those insect species represented by at least 50 individuals in each year's samples were included (Table S1). We also ran an indicator species analysis (Dufrêne and Legendre 1997) to identify potential phytophagous character species for each maple species using the "indval" function of the "labdsv" package version 2.0-1 (Roberts 2019). For NMDS and IndVal analyses, the abundance data were pooled across study years.

To determine the effect of maple species on phytophagous insects, we ran general linear mixed models (GLMMs) using the function "Ime" from the "nlme" package version 3.1143 (Pinheiro et al. 2019). The models included the yearly abundances of the main insect groups (aphids, plant- and leafhoppers and heteropterans) and species (Table S1) as response variables, tree species as an explanatory variable (fixed factor), and site as a random factor. If the model validation plots showed heteroscedasticity, we implemented a variance function "varIdent" in the weight of the models to estimate the within-group variance and account for unequal 
variances. To evaluate the effect of tree species, ANOVA tests were performed using "Anova" function of the "car" package version 3.0-6 (Fox and Weisberg 2019). For posthoc analysis, least square means were calculated using the "Ismeans" function, and pairwise comparisons with Tukey $p$ value correction were performed using the "pairs" function from the package "lsmeans" version 2.30-0 (Lenth 2016).

\section{Stress levels and condition of maple tree species}

To determine the differences between stress levels and conditions of maple species, we ran GLM and cumulative link mixed models (CLMMs) using the functions "lme" from the "nlme" package and "clmm" from the "ordinal" package version 2019.12-10 (Christensen 2019). The models included POD activity (GLMM), degree of leaf necrosis, and leaf fall (CLMMs) as response variables, tree species as an explanatory variable (fixed factor), and site as a random factor. To evaluate the differences between tree species, ANOVA tests were performed using the "Anova" function of the "car" package. For post-hoc analysis, least square means were calculated using the "lsmeans" function and pairwise comparisons with Tukey $p$ value correction were performed using the "pairs" function from the package "Ismeans."

\section{Effect of phytophagous insects on stress level of trees}

We performed two types of analyses (GLMMs) in order to examine the effect of phytophagous insects on tree stress levels using the function "Ime" from "nlme" package. In the first analysis, we tested this relationship including all tree individuals $(n=60)$. The model included POD activity as response variable, the abundance of phytophagous insect species and groups as explanatory variables (pooled abundance data across collection dates before the POD measurements in 2015, fixed factors), and tree species and site as random factors. In the following analyses, we ran models for each tree species separately $(n=20)$. The models included POD activity as a response variable, the abundances of phytophagous insect species and groups as explanatory variables (fixed factors), and site as a random factor.

\section{Relationships between phytophagous insects and tree condition}

To test the effect of phytophagous insects on the condition of trees, we ran CLMMs using the function "clmm" of the "ordinal" package. The models included the degree of leaf fall and necrosis as response variables, the abundance of phytophagous insect species and groups as explanatory variables (fixed factors), and tree species and site as random factors. We used GLMMs to assess whether the condition of trees would influence the abundance of phytophagous insects using the function "Ime" from "nlme" package. The models included the abundance of phytophagous insect species and groups as response variables, degree of leaf fall and necrosis as explanatory variables (fixed, ordered factors), and tree species and site as random factors.

\section{Results}

\section{Taxa recorded}

In total, we identified 33072 phytophagous insects, 12302, 7835 and 12935 individuals from the canopy of sycamore, Norway, and field maple, respectively. The overall abundance was similar between sycamore maple and field maple in both study years $(2014: t=1.544, p=0.285 ; 2015: t$ $=-0.650, p=0.793)$. However, the total abundance was lower on Norway than on field (2014: $t=-2.936, p=$ 0.017; 2015: $t=-2.873, p=0.016)$ and sycamore maple (2014: $t=-4.481, p<0.000 ; 2015: t=-2.223, p=0.076$ ) (Fig. 1). The collected individuals consisted mainly of planthoppers (Fulgoromorpha; 66.4\%), aphids (17.8\%), heteropterans (7.0\%), leafhoppers (Cicadomorpha; 5.3\%), curculionids $(2.5 \%)$ and psyllids (0.86\%). Metcalfa pruionosa $(n=$ 21852) was by far the most abundant species, representing $66.1 \%$ of all individuals examined, followed by Periphyllus
Fig. 1 Total abundance of collected phytophagous insects on sycamore, Norway, and field maple trees in 2014 and 2015. On the boxplots red squares indicate means. Significant differences between maple species (least square means, ANOVA, GLMM; $* p \leq 0.05, * * * p \leq$ 0.001 ) were calculated for $\log$ transformed data.

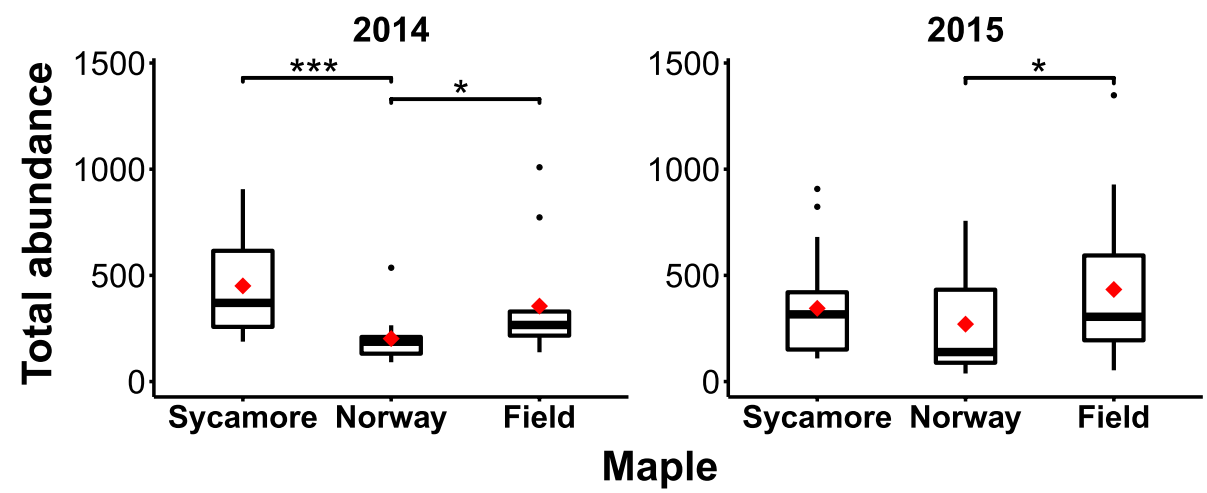




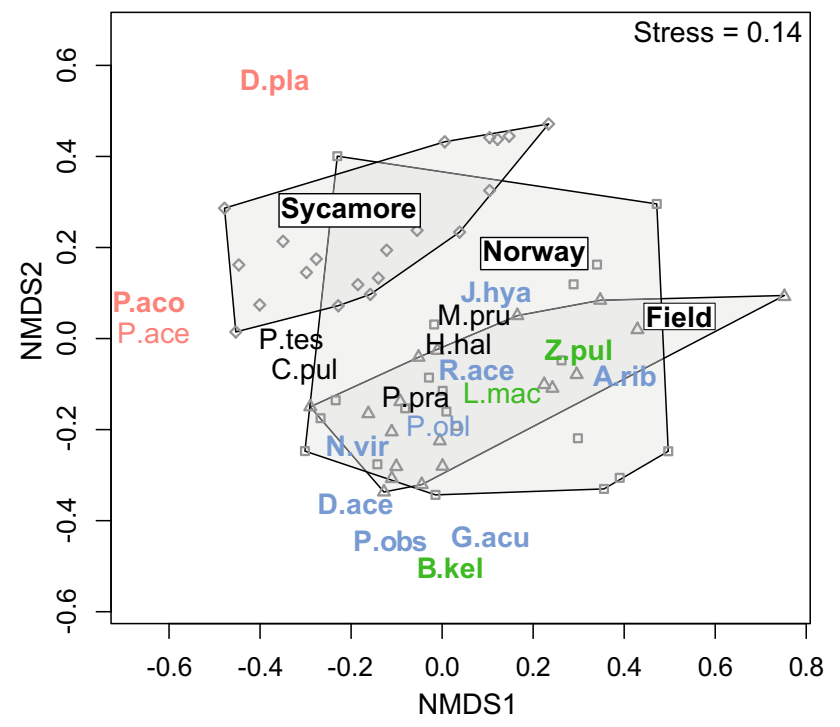

Fig. 2 NMDS ordination of trees grouped by maple species based on the community composition of abundant phytophagous insect species. Abbreviations in bold and in color represent character species with significant IndVal values $(p<0.05)$ and abbreviations in color and without bold represent character species with marginally significant IndVal values $(p \geq 0.05$ and $p<0.1)$ belonging to each maple species; red: sycamore maple, green: Norway maple, blue: field maple. For full names of species and indicator values see Table S2.

testudinaceus (Fernie) ( $n=2791,8.4 \%)$, Drepanosiphum platanoidis (Schrank) $(n=2502,7.6 \%)$, Halyomorpha halys (Stål) $(n=1182,3.6 \%)$, Phyllobius oblongus (Linnaeus) ( $n$ $=571,1.7 \%)$, Nezara viridula (Linnaeus) $(n=566,1.7 \%)$, and Acericerus ribauti Nickel \& Remane ( $n=549,1.7 \%)$ (Table S1). In general, aphids, psyllids, and curculionids had peaks in abundance earlier in the season than plant- and leafhoppers and heteropterans. For temporal abundances of phytophagous species see Figs. S1-S4.

\section{Effect of tree species on the composition and abundance of phytophagous insects}

NMDS analysis clearly separated the phytophagous insect communities of sycamore and field maple, and also showed that Norway maple had the least specific phytophagous insect community, with a high overlap especially with that of field maple (Fig. 2). Indicator species analysis identified two species, D. platanoidis and Periphyllus acericola (Walker), as character species of sycamore maple and other two species, Zyginella pulchra Low and Bradybatus kellneri Bach, as character species of Norway maple. Seven further indicator species, Drepanosiphum aceris Koch, Periphyllus obscurus Mamontova, Rhinocola aceris (Linnaeus), A. ribauti, Japananus hyalinus (Osborn), Gonocerus acuteangulatus (Goeze), and N. viridula showed a preference for field maple (Fig. 2; Table S2).
The total number of aphids was the highest on sycamore and the lowest on Norway maple trees in both years (Fig. S5, Table S3). Aphid species exhibited a high degree of host specificity. Similar to the results of the NMDS analysis, $D$. platanoidis was exclusively, and P. acericola and Periphyllus aceris (Linnaeus) were mainly associated with sycamore, while $D$. aceris and $P$. obscurus were almost exclusively associated with field maple. Periphyllus testudinaceus was abundant on both sycamore and field maple trees. In contrast, no aphid species were associated with Norway maple (Fig. 3; Table S4).

The abundance of the planthopper M. pruinosa was the highest on field maple and the lowest on Norway maple (Fig. 4; Table S4). For other planthoppers and leafhoppers, the overall abundance was significantly higher on field maple compared to sycamore maple (Fig. S5; Table S3). Latilica maculipes (Melichar) showed no preference between the three maple species (Fig. 4; Table S4). For leafhoppers, J. hyalinus was associated with field maple and Z. pulchra with Norway maple, while $A$. ribauti was associated with both (Fig. 4; Table S4).

The total abundance of heteropterans was significantly higher on field maple than on sycamore maple in 2014, but not in 2015 (Fig. S5; Table S3). We detected the lowest abundances of $G$. acuteangulatus and N. viridula on sycamore maple; however, for the latter species this difference was only significant compared to field maple. Palomena prasina (Linnaeus) had higher number of individuals on Norway maple compared to field maple in 2015. Individuals of $H$. halys occurred in same numbers on all maple species (Fig. 5; Table S4).

The psyllid $R$. aceris was associated with field maple, while we found no difference between the abundances of Cacopsylla pulchella (Low) on the three maple species. Considering curculionids, we found a significantly higher abundance of $P$. oblongus on field maple compared to sycamore maple, with intermediate abundance on Norway maple. Bradybatus kellneri was primarily associated with Norway maple (Fig. 6; Table S4).

\section{Stress levels and condition of maple tree species}

Although on average Norway maple individuals had the highest POD activity values, we did not find significant differences between maple species for this variable. In contrast, we found significant differences in the leaf necrosis levels between the maple species, which were the highest on Norway maple and were lowest on field maple. We found no statistically significant differences in leaf fall between maple species (Fig. 7; Table S5). 
Fig. 3 Abundance of aphid species on sycamore, Norway, and field maple trees in 2014 and 2015. On the boxplots red squares indicate means. Significant differences between maple species (least square means, ANOVA, GLMM; * $p \leq 0.05$, $* * p \leq 0.01, * * * p \leq 0.001)$ were calculated for log-transformed data. The main outcomes of pairwise comparisons are summarized in Table S4. Note the different scales on the y-axes.

\section{Aphids}

Drepanosiphum platanoidis 2014

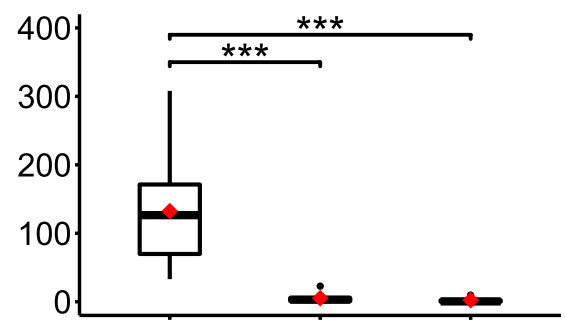

Periphyllus testudinaceus 2014

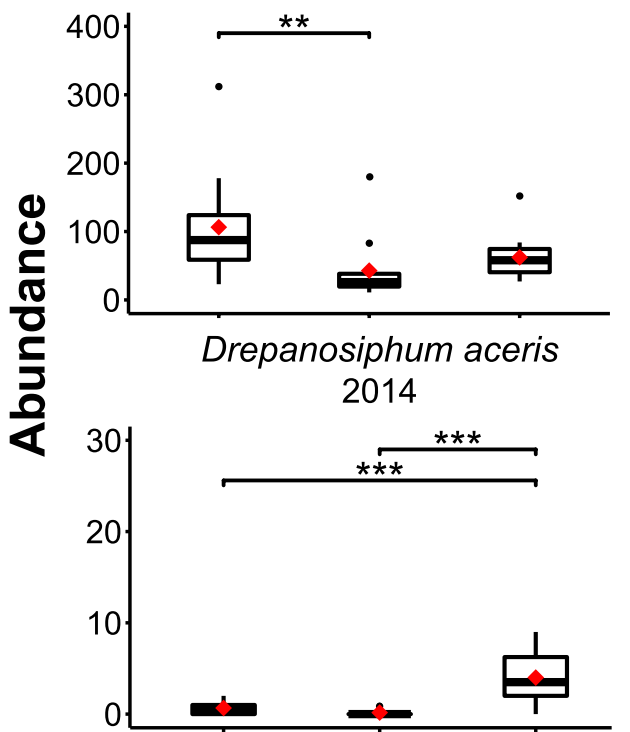

Periphyllus acericola 2014

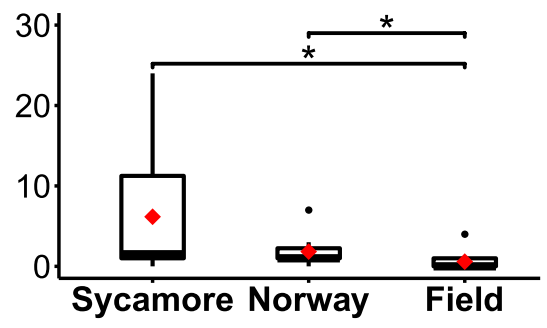

Drepanosiphum platanoidis 2015

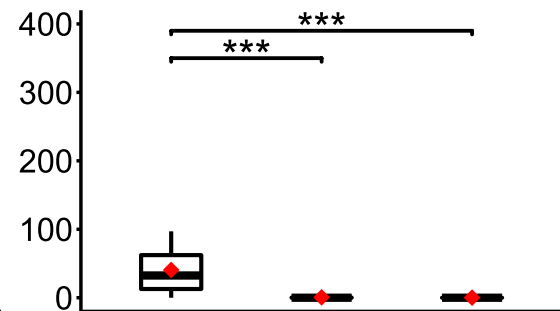

Periphyllus testudinaceus 2015

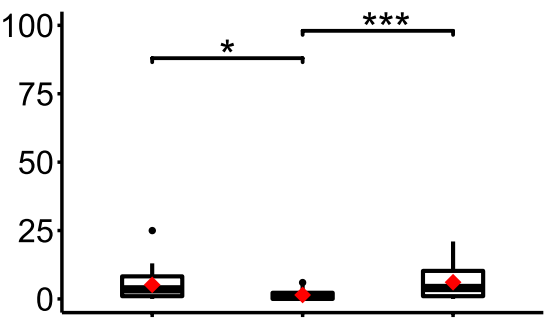

Periphyllus obscurus 2014

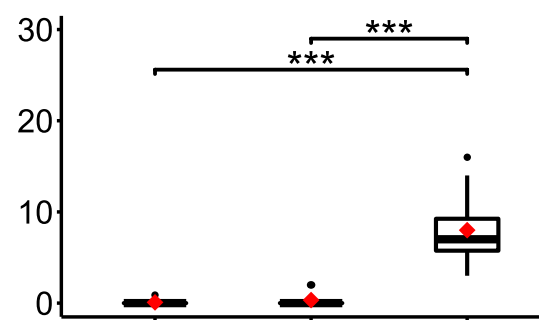

Periphyllus aceris 2014

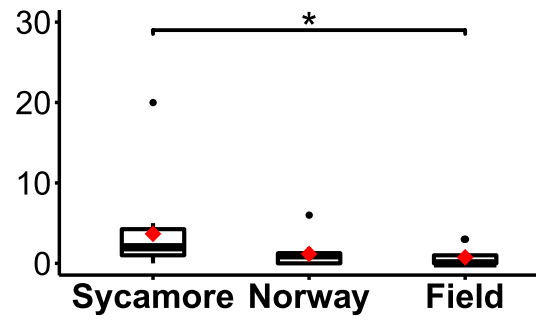
Maple

\section{Effect of phytophagous insects on stress level of trees}

Overall, we observed a significant increase in POD activity in maple trees with increasing numbers of $M$. pruinosa individuals, while the abundant phytophagous groups (other plant- and leafhoppers, aphids, and heteropterans) had no effect on this variable (Table 1). We found a significant positive relationship between $M$. pruinosa abundance and POD activity of sycamore and field maple trees, but no such relationship was found for Norway maple (Fig. 8; Table S6). The abundance of other phytophagous groups had no effect on POD activity of any of the maple species (Table S6).

\section{Relationships between phytophagous insects and tree condition}

Analyzing the relationship between the abundance of phytophagous insects and tree condition we found that the abundance of phytophagous insect groups had no significant 
Fig. 4 Abundance of plant- and leafhopper species on sycamore, Norway, and field maple trees. On the boxplots red squares indicate means. Significant differences between maple species (least square means, ANOVA, GLMM; $* p \leq 0.05, * * p \leq 0.01$, $* * * p \leq 0.001$ ) were calculated for log-transformed data. The main outcomes of pairwise comparisons are summarized in Table S4. Note the different scales on the y-axes.

\section{Plant-and leafhoppers}
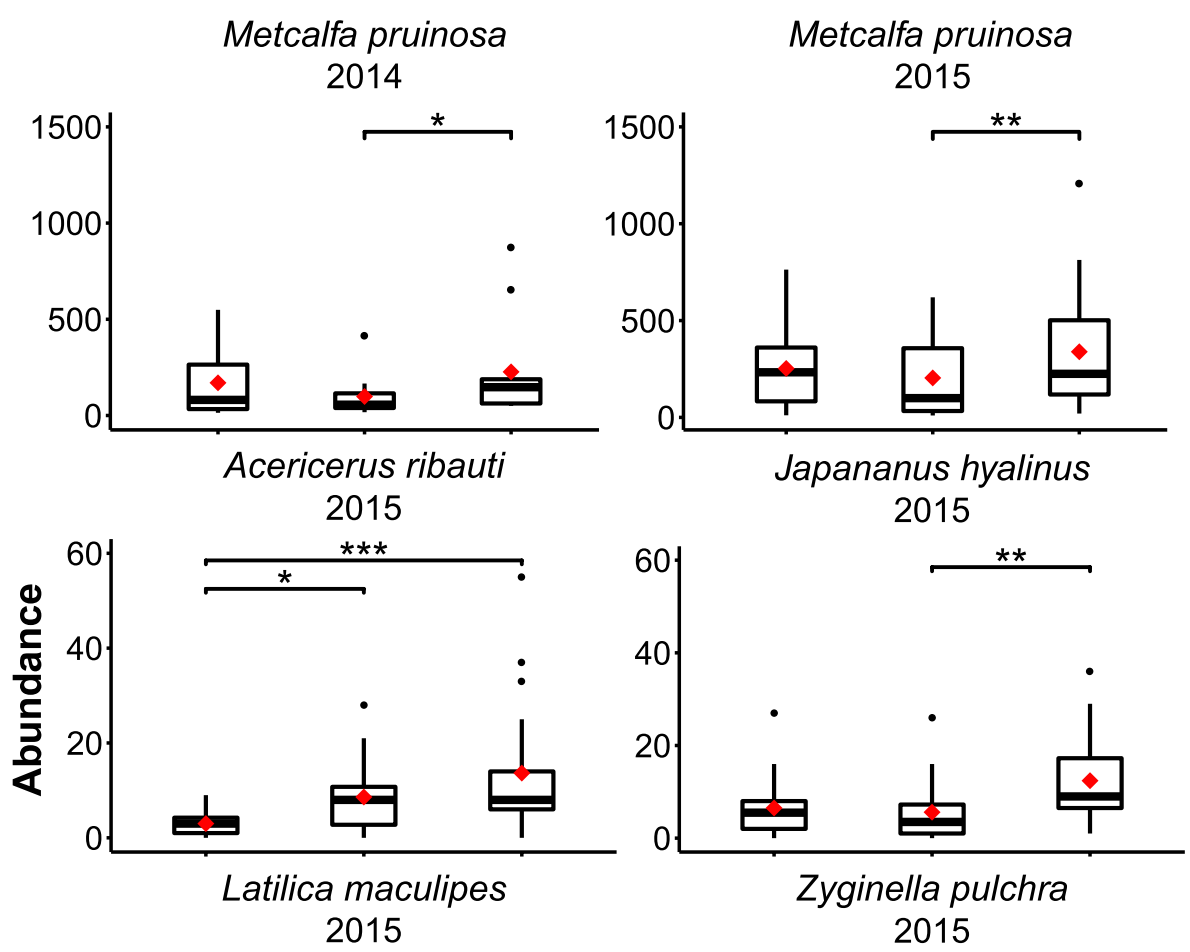

Zyginella pulchra

2015
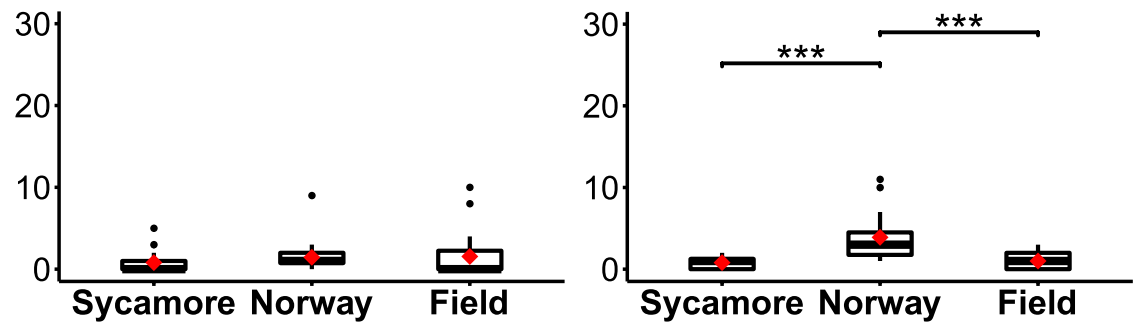

\section{Maple}

effect on the degree of leaf fall or necrosis of maple trees (Table S7). Conversely, advancing degree of leaf fall and leaf necrosis negatively affected the abundance of the superabundant species M. pruinosa (Table 2). The abundance of other insect groups showed no response to the changing conditions of the trees (Table 2).

\section{Discussion}

In this study, we showed that despite being native and congener species, sycamore, Norway, and field maple trees support phytophagous insect communities that differ in density and species composition in urban environment. We observed a higher total abundance of phytophagous insects on field and sycamore maple compared to Norway maple trees. Field maple had the most indicator species and Norway maple had the least specific phytophagous insect community. The numbers of the most abundant phytophagous insect species, M. pruinosa, were driven by tree conditions, with higher abundances on healthier trees.

\section{Objective 1: effect of tree species on the composition and abundance of phytophagous insects}

Norway maple harbored not only the least abundant, but also the least specific phytophagous insect community compared to the other two maple species. However, all the three maple species we studied are native to Hungary and, therefore, we cannot expect a much lower susceptibility to the major insect groups in Norway maple. Field and Norway maple had more overlapping, while field maple and sycamore had distinct phytophagous insect communities (Fig. 2). Phylogenetic 
Fig. 5 Abundance of heteropteran species on sycamore, Norway, and field maple trees in 2014 and 2015. On the boxplots red squares indicate means. Significant differences between maple species (least square means, ANOVA, GLMM; * $p$ $\leq 0.05, * * p \leq 0.01, * * * p \leq$ 0.001 ) were calculated for logtransformed data. The main outcomes of pairwise comparisons are summarized in Table $\mathrm{S} 4$. Note the different scales on the $\mathrm{y}$-axes.

\section{Heteropterans}

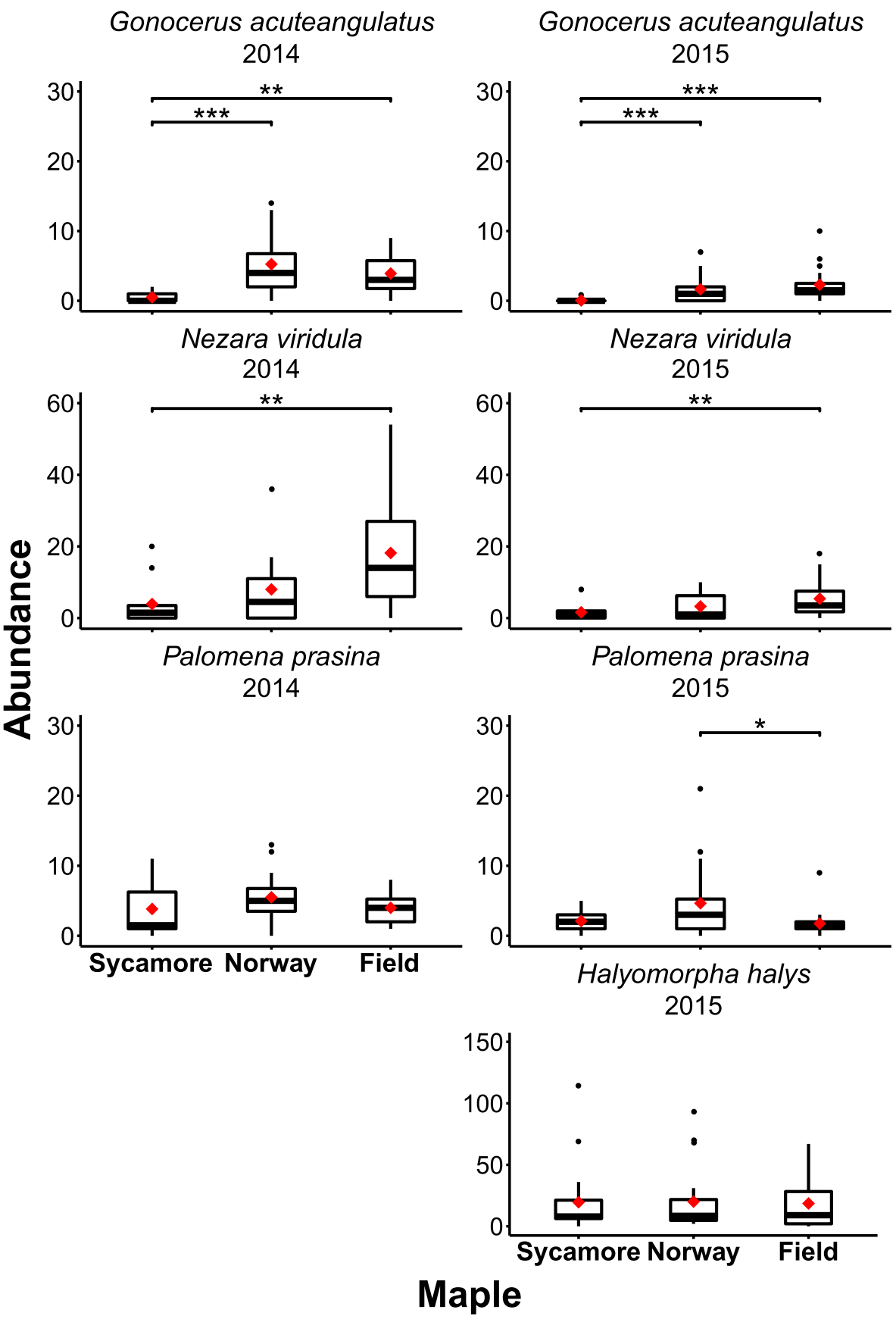

distance between the three maple species may explain this pattern (Li et al. 2006).

The abundance of aphids was the lowest on Norway maple (Fig. 3; Fig. S5). In contrast to our observations, Mackoś-Iwaszko et al. (2015) found high numbers of aphids, especially those of $P$. testudinaceus and $P$. aceris on Norway maple in urban environments. At the same time, they found that spring with little precipitation led to a decrease of the number of aphids on this maple species. Barczak et al. (2021) also registered high P. testudinaceus densities on $A$. platanoides, but mostly on tree individuals occurring on moist soil. Based on these, low aphid densities observed on Norway maple in our study may be related to the dry environmental conditions and associated poor condition of Norway maple trees in our study area. The abundance of aphids in both years was much higher on sycamore than on field maple (Fig. S5). An explanation for this difference might be that budburst of sycamore starts earlier than field maple (Lechowicz 1984), providing better phenological synchronization for aphid species with early egg hatch (e.g., for 
Fig. 6 Abundance of psyllid and curculionid species on sycamore, Norway, and field maple trees in 2014 and 2015. On the boxplots red squares indicate means. Significant differences between maple species (least square means, ANOVA, GLMM; ${ }^{*} p \leq 0.05$, $* * p \leq 0.01)$ were calculated for log-transformed data. The main outcomes of pairwise comparisons are summarized in Table S4.

\section{Other phytophagous species}

\section{Psyllids}

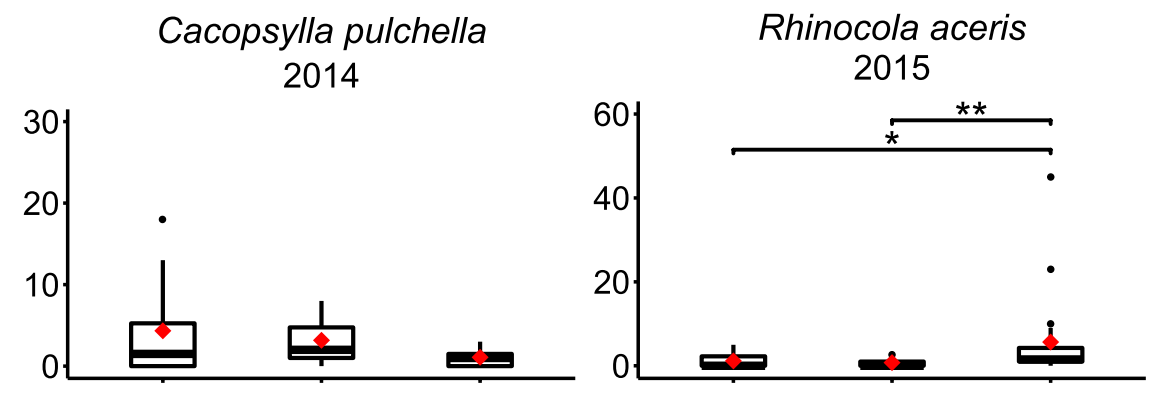

\section{Curculionids}

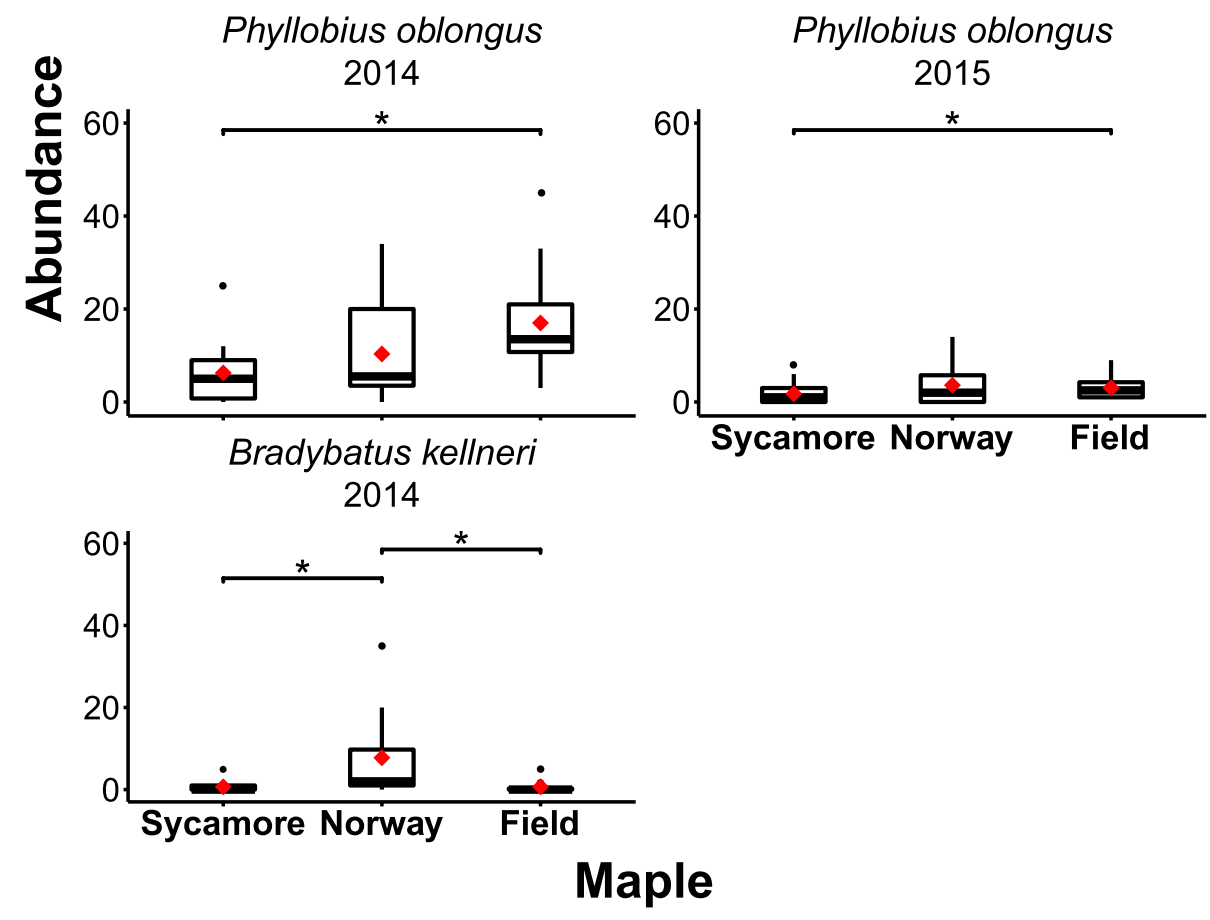

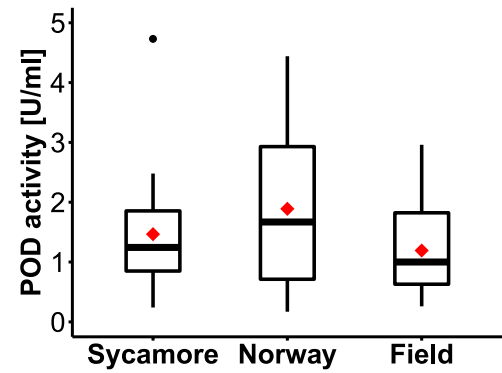
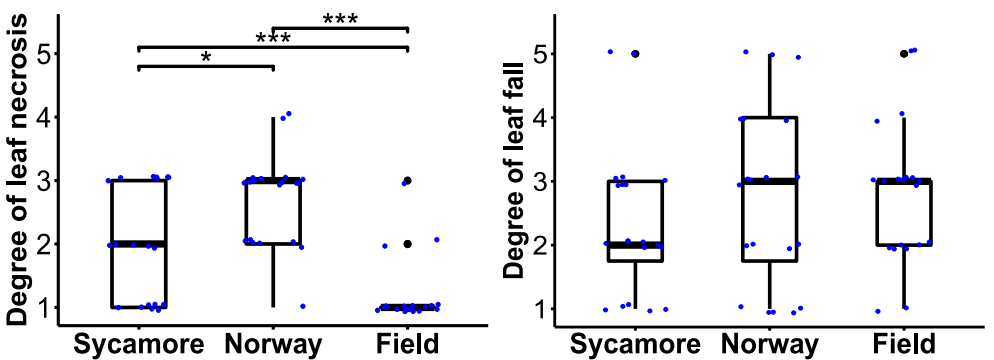

Fig. 7 POD enzyme activity, degree of leaf necrosis, and fall of sycamore, Norway, and field maple trees. On the boxplot of POD activity, red squares indicate means. In case of leaf necrosis, asterisks indicate significant differences between maple species (least square means, ANOVA, CLMM; $* p \leq 0.05, * * * p \leq 0.001)$. The main outcomes of pairwise comparisons are summarized in Table S5. 
Table 1 Results of the GLMMs for the POD enzyme activity (logtransformed data) of maple trees depending on the abundance of aphids, Metcalfa pruinosa, other (non-M. pruinosa) plant- and leafhoppers, and heteropterans

\begin{tabular}{llllll}
\hline Explanatory variable & Estimate & SE & t & Adj. $p^{*}$ & Unadj. $p$ \\
\hline $\begin{array}{lllll}\text { M. pruinosa } \\
\text { Other plant- and leaf- }\end{array}$ & 0.000 & 0.000 & 2.753 & $\mathbf{0 . 0 3 4}$ & $\mathbf{0 . 0 0 8}$ \\
$\quad$ hoppers & & 0.001 & 1.014 & 0.421 & 0.316 \\
Aphids & 0.000 & 0.001 & -0.327 & 0.745 & 0.745 \\
Heteropterans & 0.007 & 0.003 & 1.913 & 0.124 & 0.062 \\
\hline
\end{tabular}

Numbers in bold indicate significant $(p<0.05)$ and number in italics indicate marginally significant $(p \geq 0.05$ and $p<0.1) p$ values

*Benjamini-Hochberg correction

P. testudinaceus) (Fig. S1) (Dixon 1998). Regarding the host plant specificity of aphids, in line with our results, D. platanoidis and $P$. acericola are known to develop primarily on sycamore maple, D. aceris and $P$. obscurus on field maple, while $P$. testudinaceus develops mainly on field and sycamore maple (Figs. 2 and 3) (Blackman and Eastop 1994).
Our results are consistent with earlier findings that leafhopper species A. ribauti and J. hyalinus feed mainly on field maple, which seems to be the primary host plant for these species in Europe (Nickel 2003). According to Nickel (2003), Z. pulchra feed mainly on sycamore maple and less frequently on its congener species. In contrast, and in line with the observations of Wilson and Mühlethaler (2010), we found that this species can reach higher densities on Norway maple in urban settings (Figs. 2 and 4).

The abundance of most heteropteran species, mainly feeding on fruits of the trees, was the lowest on sycamore maple (Fig. 5). One explanation for this pattern might be the inadequate amount or quality of ripening fruits on sycamore trees during the second half of the growing season, when true bugs reached high abundance in the canopy (Fig. S3). The invasive and highly polyphagous stink-bug species Halyomorpha halys was first detected in Hungary in 2013 at one of our study sites (Vétek et al. 2014). Our results suggest that this species became the most abundant true bug on all examined maple species within a few years.
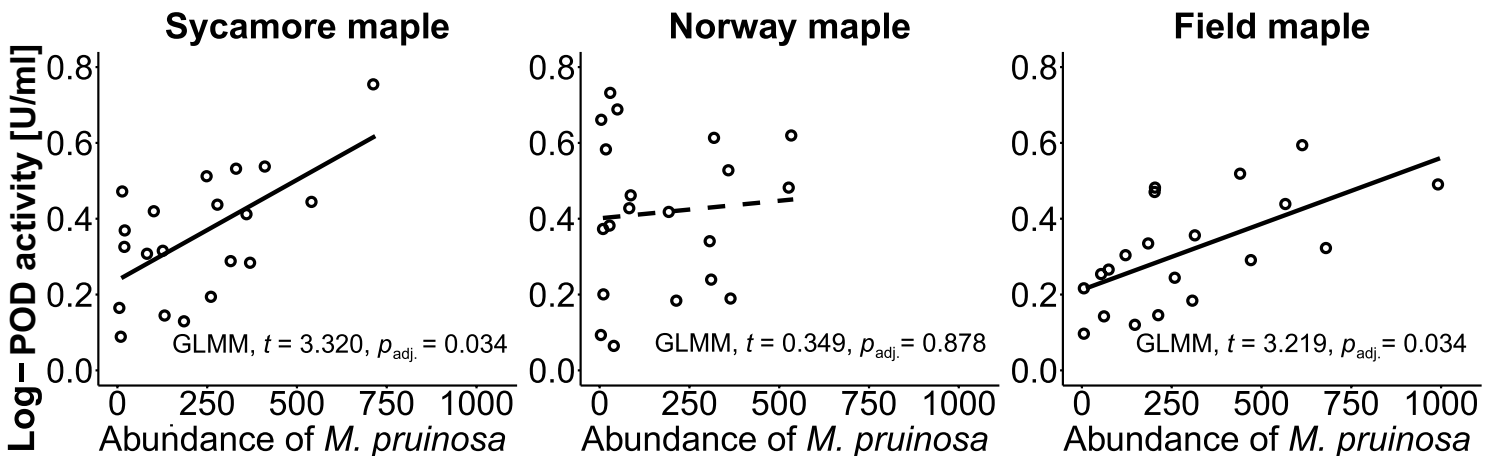

Fig. 8 Effect of the abundance of Metcalfa pruinosa on POD enzyme activity of sycamore, Norway, and field maple trees. Continuous lines indicate significant $(p<0.05)$ relationships. The main outcomes of phytophagous insect-POD activity relationships are summarized in Table S6.

Table 2 Results of the GLMMs for the abundance of aphids, Metcalfa pruinosa, other (non-M. pruinosa) plant- and leafhoppers, and heteropterans (log-transformed data), depending on the degree of leaf fall and necrosis of maple trees (ordered factors)

\begin{tabular}{lllllll}
\hline Explanatory variable & Response variable & Estimate* & SE & $t$ & Adj. $p^{* *}$ & Unadj. $p$ \\
\hline Leaf fall & M. pruinosa & -0.332 & 0.113 & -2.939 & $\mathbf{0 . 0 4 1}$ & $\mathbf{0 . 0 0 5}$ \\
& Other plant- and leafhoppers & -0.005 & 0.080 & -0.060 & 0.960 & 0.952 \\
& Aphids & -0.183 & 0.108 & -1.697 & 0.257 & 0.097 \\
Leaf necrosis & Heteropterans & 0.011 & 0.127 & 0.083 & 0.960 & 0.934 \\
& M. pruinosa & -0.320 & 0.127 & -2.521 & $\mathbf{0 . 0 4 9}$ & $\mathbf{0 . 0 1 3}$ \\
& Other plant- and leafhoppers & 0.032 & 0.102 & 0.311 & 0.960 & 0.756 \\
& Aphids & -0.010 & 0.196 & -0.051 & 0.960 & 0.960 \\
& Heteropterans & 0.232 & 0.187 & 1.242 & 0.442 & 0.221 \\
\hline
\end{tabular}

Numbers in bold indicate significant $(p<0.05)$ and number in italics indicate marginally significant $(p \geq$ 0.05 and $p<0.1) p$ values

*Positive values indicate phytophagous groups or species that increased in abundance with increasing rates of leaf fall and necrosis

${ }^{* *}$ Benjamini-Hochberg correction 
The large number of the seed-feeding curculionid, $B$. kellneri, on Norway maple (Fig. 6) was because Norway is the earliest flowering of the three tree species (WeryszkoChmielewska et al. 2016), and overwintered B. kellneri individuals search for flowers of maples after their emergence (Fig. S4) (Blake et al. 2018).

It is important to mention that nine out of the 11 character species (82\%), and four out of the eight species showing no or only a weak preference for maple species (50\%) were native to the study region (Fig. 2; Table S2). This suggests that local phytophagous insect species are more strongly associated with native trees than alien ones (Tallamy 2004; Clem and Held 2015).

\section{Objective 2: effect of phytophagous insects on stress level and condition of trees}

We found that increasing abundance of $M$. pruinosa significantly increased the POD activity of trees, but no such relationship was observed for other insect groups (Table 1). This result could be expected, since M. pruinosa was the most abundant phytophagous species in the canopy of maple trees and the POD activity measurements coincided with its activity peak (Fig. S2). As antioxidative enzymes, PODs play important role in reducing perturbations caused by reactive oxidative species, which induce oxidative damages under environmental stress conditions in plant cells (Sharma et al. 2012; War et al. 2012). PODs also regulate a number of processes that have a direct or indirect role in plant defense, including lignification or wound healing, and are known to become more active when herbivore damage occurs (Tscharntke et al. 2001; Zhang et al. 2008; War et al. 2012). In contrast to field and sycamore maple, $M$. pruinosa abundance did not affect POD activity in Norway maple, where we found trees with high stress levels even at low $M$. pruinosa densities (Fig. 8; Table S6). One reason for this may be that other, presumably abiotic factors have contributed to increased stress level of this tree species. Although POD activity assessments coincided with the highest overall abundance of phytophagous insects, aphids, as one of the most abundant insect groups, had the highest densities in spring and early summer (Fig. S1). This may explain the lack of relationship between aphids and POD activity, which was measured in the second half of the summer (Table 1).

The degree of leaf necrosis, an indicator of a tree's condition, was by far the lowest in field maple and the highest in Norway maple (Fig. 7; Table S5). Although tree condition was assessed only in the second year, this pattern was already apparent in the first year of this study (DK personal observation). Prior studies reported that the appearance of necrosis in leaves is directly or indirectly induced by abiotic stress factors, such as air pollution, drought, heavy metal contamination of soil, and salt stress (Paludan-Müller et al.
2002; Günthardt-Goerg and Vollenweider 2007; Khavaninzadeh et al. 2014). For instance, increased necrotic leaf injury was observed on Norway maple as a response to salinity stress (Marosz and Nowak 2008), elevated concentrations of particulate matter in city air (Mitrović et al. 2006), and soil alkalization (Bach and Pawłowska 2006). Furthermore, biotic factors like pathogens can also cause necrotic spotting (Hudelson et al. 2008; Held et al. 2018), although we observed a low disease (e.g., Sawadaea bicornis [Wallr.] Homma or Rhytisma acerinum [Pers.] Fries) incidence on the studied trees.

We found that field maple trees were in better condition than the other maple species (Fig. 7). Field maple is considered one of the most tolerant tree species to urban conditions due to its wide ecological plasticity, winter robustness, and resistance to drought and adverse soil conditions (Roloff et al. 2009; Swoczyna et al. 2015; Stratópoulos et al. 2019). In contrast to our expectations, Norway maple showed the most severe necrosis symptoms (Fig. 7). Norway maple is often considered to be resistant to urban conditions tolerating heat, drought, salt, and air pollution (reviewed by Sjöman and Nielsen 2010). However, in accordance with our results, under certain circumstances (e.g. high summer temperatures associated with extremely dry conditions, relatively high soil $\mathrm{pH}$, and extensive use of de-icing salt), Norway maple responds negatively to urban conditions (Fostad and Pedersen 1997; Uhrin et al. 2018).

\section{Objective 3: Effect of tree condition on phytophagous insects}

The deteriorating condition of trees (i.e., advanced leaf necrosis and leaf fall) negatively influenced the abundance of the super-dominant planthopper species, M. pruinosa (Table 2). Although we did not find a significant relationship between tree condition and aphid abundance, the total number of aphids was the lowest on Norway maple (Fig. S5; Table S3). However, we measured the condition of the trees in autumn and it is therefore difficult to speculate about its effect on phytophagous insects in the first half of the season.

Although many authors claim that stressed trees in urban areas have a greater susceptibility to attack by sap-sucking insects (e.g., Cregg and Dix 2001; Raupp et al. 2010; Dale and Frank 2017), some studies showed that these insect groups prefer trees with better conditions and healthier leaves (Hanks and Denno 1993; Huberty and Denno 2004; Sienkiewicz-Paderewska et al. 2017). According to the predictions of the Plant Stress Hypothesis, plants exposed to stress may decrease investment in defenses, which can lead to increased herbivore insect abundance (White 1984), though this effect may vary among insects from different feeding guilds (Huberty and Denno 2004). Although in this study, the vast majority of the phytophagous insects were 
phloem feeders (aphids, plant- and leafhoppers, and psyllids) (Hodkinson 1974; Dixon 1998; Nickel 2003), they differed in their response to host plant condition (observed either within or between Acer species). In addition to host plant specificity of phytophagous species, seasonality and severity of plant stress may be responsible for these differences in abundance patterns (Huberty and Denno 2004; Gely et al. 2020).

Metcalfa pruinosa is a highly polyphagous, devastating pest of ornamental trees in Europe (Alma et al. 2005, Strauss 2010). Our results suggest that its abundance in the canopy of maple trees is determined primarily by the tree condition and to a lesser extent by the species of the studied maple hosts.

\section{Conclusions}

In this study we characterized the phytophagous insect communities in the canopy of three maple species (Acer pseudoplatanus, A. platanoides and A. campestre), native to Europe and commonly used in urban plantings. Our results showed that the three maple species support characteristic phytophagous insect communities, which are primarily determined by the species of the host plant. Maple trees differed markedly in their condition, expressed as degree of leaf necrosis, where field maple was in the best and Norway maple in the worst condition in the urban environment. Consistent with that finding, field maple had the most indicator species while Norway maple had the least specific phytophagous insect community, with the lowest abundance. Numbers of the super-abundant planthopper species, M. pruinosa, were driven by tree condition, achieving higher abundances on healthier trees.

Our results suggest that field maple can cope with the negative effects of urbanization, including abiotic stressors and outbreaks of phytophagous insects, and that therefore this species is well-suited to urban habitats.

Supplementary Information The online version contains supplementary material available at https://doi.org/10.1007/s11829-022-09887-z.

Acknowledgements The authors are grateful to András Orosz and Attila Podlussány for their help in identifying some plant- and leafhopper and curculiondid species, respectively, and to Éva StefanovicsBányai and Réka Rédei for their contribution to the laboratory assays. We also thank Róbert Gallé for his helpful suggestions on data analysis.

Funding Open access funding provided by ELKH Centre for Ecological Research. This research was supported by the National Research, Development and Innovation Office of Hungary (K129311).

\section{Declarations}

Conflict of interest The authors declare that they have no conflict of interest.

Open Access This article is licensed under a Creative Commons Attribution 4.0 International License, which permits use, sharing, adaptation, distribution and reproduction in any medium or format, as long as you give appropriate credit to the original author(s) and the source, provide a link to the Creative Commons licence, and indicate if changes were made. The images or other third party material in this article are included in the article's Creative Commons licence, unless indicated otherwise in a credit line to the material. If material is not included in the article's Creative Commons licence and your intended use is not permitted by statutory regulation or exceeds the permitted use, you will need to obtain permission directly from the copyright holder. To view a copy of this licence, visit http://creativecommons.org/licenses/by/4.0/.

\section{References}

Alma A, Ferracini C, Burgio G (2005) Development of a sequential plan to evaluate Neodryinus typhlocybae (Ashmead) (Hymenoptera: Dryinidae) population associated with Metcalfa pruinosa (Say) (Homoptera: Flatidae) infestation in northwestern Italy. Environ Entomol 34:819-824. https://doi.org/10.1603/0046225X-34.4.819

Bach A, Pawłowska B (2006) Effect of sodium chloride salinity and $\mathrm{pH}$ of soil on ornamental urban trees in Kraków with regard to nature conservation in cities. Ecol Chem Eng A 13:455-461

Barczak T, Bennewicz J, Korczyński M, Błażejewicz-Zawadzińska M, Piekarska-Boniecka H (2021) Aphid assemblages associated with urban park plant communities. Insects 12:173. https://doi.org/10. 3390/insects 12020173

Basset Y, Aberlenc H-P, Springate ND, Delvare G (1997) A review of methods for sampling arthropods in tree canopies. In: Stork NE, Adis JA, Didham RK (eds) Canopy arthropods. Chapman \& Hall, London, pp 27-52

Benjamini Y, Hochberg Y (1995) Controlling the false discovery rate: a practical and powerful approach to multiple testing. J R Stat Soc Ser B 57:289-300. https://doi.org/10.1111/j.2517-6161.1995. tb02031.x

Blackman RL, Eastop VF (1994) Aphids on the world's trees. An identification and information guide. CAB International, Oxford

Blake M, Barclay MV, Mendel H, Morris MG (2018) Bradybatus kellneri Bach, 1854 (Curculionidae) intercepted in Acer fruits - one to watch out for in Britain. The Coleopterist 27:91-94

Britt C, Johnston M (2008) Trees in Towns II: a new survey of urban trees in England and their condition and management (executive summary). Technical report. London: Department of Communities and Local Government, London

Caudullo G, de Rigo D (2016) Acer platanoides in Europe: distribution, habitat, usage and threats. In: San-Miguel-Ayanz J, de Rigo D, Caudullo G, Houston Durrant T, Mauri A (eds) European Atlas of Forest Tree Species. Publication Office of the European Union, Luxembourg, pp e019159+

Christensen RHB (2019) Ordinal-Regression Models for Ordinal Data. R package version 2019.12-10. https://CRAN.R-project.org/packa ge $=$ ordinal

Clem CS, Held DW (2015) Species richness of eruciform larvae associated with native and alien plants in the southeastern United States. J Insect Conserv 19:987-997. https://doi.org/10.1007/ s10841-015-9815-0 
Close RE, Nguyen PV, Kielbaso JJ (1996) Urban vs. natural sugar maple growth: I. Stress symptoms and phenology in relation to site characteristics. J Arboric 22:144-150

Cowett FD, Bassuk NL (2014) Statewide assessment of street trees in New York State, USA. Urban For Urban Green 13:213-220. https://doi.org/10.1016/j.ufug.2014.02.001

Cowett FD, Bassuk NL (2020) Street tree diversity in Massachusetts, USA. Arboricult Urban For 46:27-43

Cregg BM, Dix ME (2001) Tree moisture stress and insect damage in urban areas in relation to heat island effects. J Arboric 27:8-17

Dale AG, Frank SD (2017) Warming and drought combine to increase pest insect fitness on urban trees. PLoS ONE 12:e0173844. https:// doi.org/10.1371/journal.pone. 0173844

Dixon AFG (1971) The role of aphids in wood formation. I. The effect of the sycamore aphid, Dreopanosiphum platanoides (Schr.) (Aphididae), on the growth of sycamore, Acer pseudoplatanus (L.). J Appl Ecol 8:165-179. https://doi.org/10.2307/2402135

Dixon AFG (1998) Aphid ecology: an optimization approach, 2nd edn. Chapman and Hall, New York

Dobrowolska I, Kurczynska EU, Dmuchowski W (2001) Anatomy of abscission zone of Betula pendula (Roth.) leaves from trees growing under different levels of pollution. Dendrobiology 46:13-19

Dufrêne M, Legendre P (1997) Species assemblages and indicator species: the need for a flexible asymmetrical approach. Ecol Monogr 67:345-366. https://doi.org/10.1890/0012-9615(1997)067[0345: SAAIST]2.0.CO;2

Ekholm A, Tack AJ, Bolmgren K, Roslin T (2019) The forgotten season: the impact of autumn phenology on a specialist insect herbivore community on oak. Ecol Entomol 44:425-435. https://doi. org/10.1111/een.12719

Fostad O, Pedersen PA (1997) Vitality, variation, and causes of decline of trees in Oslo center (Norway). J Arboric 23:155-165

Fox J, Weisberg S (2019) An R Companion to Applied Regression, 3rd edn. Sage, Thousand Oaks CA. Retrieved from https://socialscie nces.mcmaster.ca/jfox/Books/Companion/

Frank SD, Klingeman WE, White SA, Fulcher A (2013) Biology, injury, and management of maple tree pests in nurseries and urban landscapes. J Integr Pest Manag 4:1-14. https://doi.org/10.1603/ IPM12007

Frank SD, Backe KM, McDaniel C, Green M, Widney S, Dunn RR (2019) Exotic urban trees conserve similar natural enemy communities to native congeners but have fewer pests. PeerJ 7:e6531. https://doi.org/10.7717/peerj.6531

Fraser SM (1997) Host specificity in forest insects. In: Watt AD, Stork NE, Hunter MD (eds) Forests and insects. Chapman \& Hall, London, pp 15-33

Gely C, Laurance SG, Stork NE (2020) How do herbivorous insects respond to drought stress in trees? Biol Rev 95:434-448. https:// doi.org/10.1111/brv.12571

Grimm NB, Faeth SH, Golubiewski NE, Redman CL, Wu J, Bai X, Briggs JM (2008) Global change and the ecology of cities. Science 319:756-760. https://doi.org/10.1126/science.1150195

Günthardt-Goerg MS, Vollenweider P (2007) Linking stress with macroscopic and microscopic leaf response in trees: new diagnostic perspectives. Environ Pollut 147:467-488. https://doi.org/10. 1016/j.envpol.2006.08.033

Hanks LM, Denno RF (1993) Natural enemies and plant water relations influence the distribution of an armored scale insect. Ecology 74:1081-1091. https://doi.org/10.2307/1940478

Held BW, Hoffmeister D, Blanchette RA (2018) Occurrence of European tar spot (Rhytisma acerinum) on Norway maple (Acer platanoides) causing severe infections in Minnesota. Plant Dis 102:2655-2655. https://doi.org/10.1094/PDIS-05-18-0816-PDN

Hodkinson ID (1974) The biology of the Psylloidea (Homoptera): a review. Bull Entomol Res 64:325-338
Huberty AF, Denno RF (2004) Plant water stress and its consequences for herbivorous insects: a new synthesis. Ecology 85:1383-1398. https://doi.org/10.1890/03-0352

Hudelson B, Smith D, Stanosz G, Hanson M (2008) First report of Sawadaea tulasnei powdery mildew of Norway maple (Acer platanoides) in Wisconsin. Plant Dis 92:485-485. https://doi.org/10. 1094/PDIS-92-3-0485A

Jones EW (1945) Acer L. J Ecol 32:215-219. https://doi.org/10.2307/ 2256711

Kaakeh W, Pfeiffer DG, Marini RP (1992) Combined effects of spirea aphid (Homoptera: Aphididae) and nitrogen fertilization on net photosynthesis, total chlorophyll content, and greenness of apple leaves. J Econ Entomol 85:939-946. https://doi.org/10.1093/jee/ 85.3.939

Khavaninzadeh AR, Veroustraete F, Buytaert JAN, Samson R (2014) Leaf injury symptoms of Tilia sp. as an indicator of urban habitat quality. Ecol Indic 41:58-64. https://doi.org/10.1016/j.ecolind. 2014.01.014

Lechowicz MJ (1984) Why do temperate deciduous trees leaf out at different times? Adaptation and ecology of forest communities. Am Nat 124:821-842. https://doi.org/10.1086/284319

Lenth RV (2016) Least-squares means: the R package lsmeans. J Stat Sofw 69:1-33. https://doi.org/10.18637/jss.v069.i01

Li J, Yue J, Shoup S (2006) Phylogenetics of Acer (Aceroideae, Sapindaceae) based on nucleotide sequences of two chloroplast non-coding regions. Harvard Pap Bot 11:101-115. https://doi. org/10.3100/1043-4534(2006)11[101:POAASB]2.0.CO;2

Mackoś-Iwaszko E, Lubiarz M, Karczmarz K (2015) The impact of urban conditions on the occurrence of aphids on Acer platanoides L. Acta Sci Pol 14:189-207

Marosz A, Nowak JS (2008) Effect of salinity stress on growth and macroelements uptake of four tree species. Dendrobiology 59:23-29

Matter SF, Brzyski JR, Harrison CJ, Hyams S, Loo C, Loomis J, Lubbers HR, Seastrum L, Stamper TI, Stein AM, Stokes R, Wilkerson BS (2012) Invading from the garden? A comparison of leaf herbivory for exotic and native plants in natural and ornamental settings. Insect Sci 19:677-682. https://doi.org/10. 1111/j.1744-7917.2012.01524.x

McDonnell MJ, Pickett ST (1990) Ecosystem structure and function along urban-rural gradients: an unexploited opportunity for ecology. Ecology 71:1232-1237. https://doi.org/10.2307/ 1938259

McIntyre NE (2000) Ecology of urban arthropods: a review and a call to action. Ann Entomol Soc Am 93:825-835. https://doi.org/10. 1603/0013-8746(2000)093[0825:EOUAAR]2.0.CO;2

Miles LS, Breitbart ST, Wagner HH, Johnson MT (2019) Urbanization shapes the ecology and evolution of plant-arthropod herbivore interactions. Front Ecol Evol 7:310. https://doi.org/10.3389/fevo. 2019.00310

Mitrović M, Pavlović P, Djurdjević L, Gajić G, Kostić O, Bojović S (2006) Differences in Norway maple leaf morphology and anatomy among polluted (Belgrade city parks) and unpolluted (Maljen Mt.) landscapes. Ekol Bratislava 25:126-137

Nickel H (2003) The Leafhoppers and Planthoppers of Germany (Hemiptera Auchenorrhyncha): Patterns and strategies in a highly diverse group of phytophagous insects. Pensoft Publishers, SofiaMoscow and Goecke \& Evers, Keltern

Nowak DJ, Crane DE, Stevens JC (2006) Air pollution removal by urban trees and shrubs in the United States. Urban For Urban Green 4:115-123. https://doi.org/10.1016/j.ufug.2006.01.007

Oksanen J, Blanchet FG, Friendly M, Kindt R, Legendre P, McGinn D, Minchin PR, O'Hara RB, Simpson GL, Sólymos P, Stevens MHH, Szoecs E, Wagner H (2019) vegan: community ecology package. R Package Version 2.5-6. https://CRAN.R-project.org/ package $=$ vegan 
Paludan-Müller G, Saxe H, Pedersen LB, Randrup TB (2002) Differences in salt sensitivity of four deciduous tree species to soil or airborne salt. Physiol Plant 114:223-230. https://doi.org/10. 1034/j.1399-3054.2002.1140208.x

Pandey VP, Awasthi M, Singh S, Tiwari S, Dwivedi UN (2017) A comprehensive review on function and application of plant peroxidases. Biochem Anal Biochem 6:308. https://doi.org/10.4172/ 2161-1009.1000308

Pasta S, de Rigo D, Caudullo G (2016) Acer pseudoplatanus in Europe: distribution, habitat, usage and threats. In: San-Miguel-Ayanz J, de Rigo D, Caudullo G, Houston Durrant T, Mauri A (eds) European Atlas of Forest Tree Species. Publication Office of the European Union, Luxembourg, pp e01665a+

Pautasso M, Schlegel M, Holdenrieder O (2015) Forest health in a changing world. Microb Ecol 69:826-842. https://doi.org/10. 1007/s00248-014-0545-8

Pinheiro J, Bates D, DebRoy S, Sarkar D, Team, RC (2019) nlme: Linear and Nonlinear Mixed Effects Models. R package version 3.1-143. https://CRAN.R-project.org/package $=$ nlme

Price PW (1991) The plant vigor hypothesis and herbivore attack. Oikos 62:244-251. https://doi.org/10.2307/3545270

R Core Team (2019) R: a language and environment for statistical computing. R Foundation for Statistical Computing, Vienna. ISBN 3-900051-07-0. http://www.R-project.org/. Accessed 20 Jan 2020

Rahman MA, Moser A, Rötzer T, Pauleit S (2017) Within canopy temperature differences and cooling ability of Tilia cordata trees grown in urban conditions. Build Environ 114:118-128. https:// doi.org/10.1016/j.buildenv.2016.12.013

Raupp MJ, Shrewsbury PM, Herms DA (2010) Ecology of herbivorous arthropods in urban landscapes. Annu Rev Entomol 55:19-38. https://doi.org/10.1146/annurev-ento-112408-085351

Richards NA (1983) Diversity and stability in a street tree population. Urban Ecol 7:159-171. https://doi.org/10.1016/0304-4009(83) 90034-7

Roberts DW (2019) labdsv: Ordination and multivariate analysis for ecology. R package version 2.0-1. https://CRAN.R-project.org/ package $=$ labdsv

Roloff A, Korn S, Gillner S (2009) The climate-species-matrix to select tree species for urban habitats considering climate change. Urban For Urban Green 8:295-308. https://doi.org/10.1016/j.ufug.2009. 08.002

Sæbø A, Benedikz T, Randrup TB (2003) Selection of trees for urban forestry in the Nordic countries. Urban For Urban Green 2:101114. https://doi.org/10.1078/1618-8667-00027

Schreuder MD, Van Hove LW, Brewer CA (2001) Ozone exposure affects leaf wettability and tree water balance. New Phytol 152:443-454. https://doi.org/10.1046/j.0028-646X.2001.00272.x

Seto KC, Güneralp B, Hutyra LR (2012) Global forecasts of urban expansion to 2030 and direct impacts on biodiversity and carbon pools. P Natl Acad Sci USA 109:16083-16088. https://doi.org/ 10.1073/pnas.1211658109

Shannon LM, Kay E, Lew JY (1966) Peroxidase isozymes from horseradish roots. J Biol Chem 241:2166-2172

Sharma P, Jha AB, Dubey RS, Pessarakli M (2012) Reactive oxygen species, oxidative damage, and antioxidative defense mechanism in plants under stressful conditions. J Bot 2012:1-26. https://doi. org/10.1155/2012/217037

Sienkiewicz-Paderewska D, Dmuchowski W, Baczewska AH, Bragoszewska P, Gozdowski D (2017) The effect of salt stress on lime aphid abundance on Crimean linden (Tilia 'Euchlora') leaves. Urban For Urban Green 21:74-79. https://doi.org/10. 1016/j.ufug.2016.11.010

Sjöman H, Nielsen AB (2010) Selecting trees for urban paved sites in Scandinavia-a review of information on stress tolerance and its relation to the requirements of tree planners. Urban For Urban Green 9:281-293. https://doi.org/10.1016/j.ufug.2010.04.001
Sjöman H, Östberg J, Bühler O (2012) Diversity and distribution of the urban tree population in ten major Nordic cities. Urban For Urban Green 11:31-39. https://doi.org/10.1016/j.ufug.2011.09.004

Stratópoulos LMF, Zhang C, Duthweiler S, Häberle KH, Rötzer T, Xu C, Pauleit S (2019) Tree species from two contrasting habitats for use in harsh urban environments respond differently to extreme drought. Int J Biometeorol 63:197-208. https://doi.org/10.1007/ s00484-018-1653-9

Strauss G (2010) Pest risk analysis of Metcalfa pruinosa in Austria. J Pest Sci 83:381-390. https://doi.org/10.1007/s10340-010-0308-3

Swoczyna T, Kalaji HM, Pietkiewicz S, Borowski J (2015) Ability of various tree species to acclimation in urban environments probed with the JIP-test. Urban For Urban Green 14:544-553. https://doi. org/10.1016/j.ufug.2015.05.005

Tallamy DW (2004) Do alien plants reduce insect biomass? Consery Biol 18:1689-1692. https://doi.org/10.1111/j.1523-1739.2004. 00512.x

Tscharntke T, Thiessen S, Dolch R, Boland W (2001) Herbivory, induced resistance, and interplant signal transfer in Alnus glutinosa. Biochem Syst Ecol 29:1025-1047. https://doi.org/10.1016/ S0305-1978(01)00048-5

Tubby KV, Webber JF (2010) Pests and diseases threatening urban trees under a changing climate. Forestry 83:451-459. https://doi.org/ 10.1093/forestry/cpq027

Uhrin P, Supuka J, Billiková M (2018) Growth adaptability of Norway maple (Acer platanoides L.) to urban environment. Folia Oecol 45:33-45. https://doi.org/10.2478/foecol-2018-0004

Vétek G, Papp V, Haltrich A, Rédei D (2014) First record of the brown marmorated stink bug, Halyomorpha halys (Hemiptera: Heteroptera: Pentatomidae), in Hungary, with description of the genitalia of both sexes. Zootaxa 3780:94-200. https://doi.org/10.11646/ zootaxa.3780.1.8

War AR, Paulraj MG, Ahmad T, Buhroo AA, Hussain B, Ignacimuthu S, Sharma HC (2012) Mechanisms of plant defense against insect herbivores. Plant Signal Behav 7:1306-1320. https://doi.org/10. 4161/psb.21663

Wargo PM (1996) Consequences of environmental stress on oak: predisposition to pathogens. Ann Sci For 53:359-368

Weryszko-Chmielewska E, Piotrowska-Weryszko K, Haratym W, Dmitruk M, Sulborska A, Vorobets N (2016) Changes in the pollen seasons of Acer spp. in Lublin, central- eastern Poland, in 2001-2015. Acta Agrobot 69:1670. https://doi.org/10.5586/aa. 1670

White TCR (1969) An index to measure weather-induced stress of trees associated with outbreaks of psyllids in Australia. Ecology 50:905-909. https://doi.org/10.2307/1933707

White TCR (1984) The abundance of invertebrate herbivores in relation to the availability of nitrogen in stressed food plants. Oecologia 6:90-105. https://doi.org/10.1007/BF00379790

Wilkaniec B, Sztukowska K (2008) Periphyllus testudinaceus (Fernie, 1852) (Hemiptera, Aphidoidea) number dynamics on the domestic species of maple-trees. Aphid Other Hemipterous Insects 14:83-89

Wilson MR, Mühlethaler R (2010) The nymph of Zyginella pulchra Low, 1885. Cicadina 11:43-45

Zecchin B, Caudullo G, de Rigo D (2016) Acer campestre in Europe: distribution, habitat, usage and threats. In: San-Miguel-Ayanz J, de Rigo D, Caudullo G, Houston Durrant T, Mauri A (eds) European Atlas of Forest Tree Species. Publication Office of the European Union, Luxembourg, pp e012c65+

Zhang SZ, Hua BZ, Zhang F (2008) Induction of the activities of antioxidative enzymes and the levels of malondialdehyde in cucumber seedlings as a consequence of Bemisia tabaci (Hemiptera: Aleyrodidae) infestation. Arthropod Plant Interact 2:209-213. https:// doi.org/10.1007/s 11829-008-9044-5 
Zvereva EL, Lanta V, Kozlov MV (2010) Effects of sap-feeding insect herbivores on growth and reproduction of woody plants: a metaanalysis of experimental studies. Oecologia 163:949-960. https:// doi.org/10.1007/s00442-010-1633-1

Publisher's Note Springer Nature remains neutral with regard to jurisdictional claims in published maps and institutional affiliations. 